\title{
Effects of different soil sampling instruments on assessing soil fertility in the caatinga area, Brazil
}

\author{
Vinicius Mendes de Azevedo ${ }^{1}$, Duarte Barbosa ${ }^{3}$, Fernando José Freire ${ }^{1}$, Luis Carlos \\ Marangon $^{3}$, Emídio Cantídio Almeida de Oliveira ${ }^{2 \star}$, Alexandre Tavares da Rocha ${ }^{2}$, \\ Alexandre Campelo de Oliveira ${ }^{1}$ and Marcos Ribeiro da Silva Vieira ${ }^{2}$
}

\footnotetext{
${ }^{1}$ Departamento de Agronomia, Universidade Federal Rural de Pernambuco, CEP: 52171-900, Recife, PE, Brasil. ${ }^{2}$ Unidade Acadêmica de Serra Talhada, Universidade Federal Rural de Pernambuco, CEP: 59909-460, Serra Talhada, PE, Brasil.

${ }^{3}$ Departamento de Ciência Florestal, Universidade Federal Rural de Pernambuco, CEP: 52171-900, Recife, PE, Brasil.
}

\begin{abstract}
Soil sampling is designed to ensure obtaining reliable information about the existence, concentration and distribution of the analyzed substances in the investigated area. The caatinga is usually characterized as tree and shrub formations, mostly with high fertility soils, but suffering major physical limitations. This study aimed at determining the minimum number of single samples that theoretically should be used to form a composite sample representative of the depths 0 to 10,10 to 20 , and 20 to 30 for the chemical characteristics: $\mathrm{pH}, \mathrm{P}, \mathrm{K}^{+}, \mathrm{Ca}^{2+}$ and $\mathrm{Mg}^{2+}$, as well as show that the average fertility estimated from the arithmetic mean of the results of single samples did not differ statistically from that estimated from the chemical analysis of the composite sample and statistically evaluate the effects of collection instruments (auger, cut-shovel and cup-auger) at a depth of $\mathbf{0}$ to 10 in the main indices of soil fertility. The study was conducted in a caatinga area near the city of Arcoverde, State of PernambucoPE. Samples were collected from 40 plots of $250 \mathrm{~m}^{2}$. The minimum number of simple samples that should be used to form a representative composite sample for fertility indices increases with decreasing angular error. According to the results, there was less spatial variability to the $\mathrm{pH}$ at all depths analyzed. Below $0.2 \mathrm{~m}$, the number samples to be at maximum for proper estimations of $\mathbf{P}$ and $\mathrm{K}^{+}$levels in soils. A smaller number of samples can be taken for the variables, $\mathbf{p H}, \mathrm{Ca}^{2+}$ and $\mathbf{M g}^{2^{+}}$. Significant differences in rates of fertility $\left(\mathrm{pH}, \mathrm{P}\right.$ and $\left.\mathrm{Mg}^{2+}\right)$ were observed among the instruments. The order of variability was different for all instruments. There were no differences in fertility rates for the average of single samples over the average of composite samples consisting of three simple subsamples.
\end{abstract}

Key words: Soil analysis, collection instrument, variability.

\section{INTRODUCTION}

The term "caatinga" is of Tupi origin and means "white forest"; it refers to the aspect of vegetation during the dry season, when most trees lose leaves and the whitish and bright stems dominate the landscape (Prado, 2003). The semi-arid caatinga of northeastern PE (Pernambuco) occupies $735 \mathrm{~km}^{2}$, being bounded on the east and west 
by the Atlantic and Amazonian forests, respectively and on the south by the Cerrado. It is composed of numerous botanical families of herbs, shrubs, trees and vines; this vegetation has been classified as steppes-savanna, ranked in several typologies (lbge, 1992). This vegetation presents adaptive morphological and physiological mechanisms to persist in a dry environment, where water available for plants is derived solely from the short rainy season (Fernandes, 1998).

Droughts and dry spells occur in large extensions and high evapo-transpiration rates because high temperatures favor the occurrence of water deficits (Paupitz, 2009). Average annual temperatures are relatively high, 26 to $29^{\circ} \mathrm{C}$, and the average insolation is $2800 \mathrm{~h} /$ year (Alves, 2007).

The caatinga soils, although mostly of high fertility, theysuffer from major physical limitations with respect to depth, stoniness and topography (Almeida, 2008). Chemical analysis of soil samples is the most widespread technique among the existing methods for the assessment of soil fertility and aims at quantifying the nutrient content in the soil (Santos et al., 2009).

The soil sampling techniques differ from environment to environment; thus a single sample represents a soil area in a universe of high spatial variability. The soil variability is the result of complex interactions of factors and processes of its formation. In addition to the factors and processes, soil and crop management practices are additional causes of variability (Coráje, 1997; Santos et al., 2009).

The greater the variability of a soil characteristic, the appropriate representation of a composite sample is directly related to the quantity and quality of single samples (Guarçoni et al., 2006). Thus, the chemical characteristics of a sample will be more representative when its distribution across a sampled universe is greater.

There is not a single pre-established instrument for collecting samples for soil fertility analysis. Soil samplers commonly used in Brazil include the screw-auger, auger, dutch auger and cut-shovel (Alvarez and Guarçoni, 2003; Guarçoni et al., 2007; Oliveira et al., 2007).

Using an auger in the place of the cut-shovel has the advantage of greater speed in the sampling of simple samples and handling and transport of a smaller soil volume in the field prior to homogenization (Salet et al., 2005). But, the lower soil volume collected with auger causes increased variability of soil fertility rates, making it necessary to collect more simple samples to form a representativecomposite sample (Oliveira et al., 2007). Schlindwein and Anghinon (2002) evaluated the influence of the data collection instrument (screw-auger and cutshovel) of the soil sample on measures of average and variability of chemical characteristics of a clayey Oxisol. For all chemical characteristicsanalyzed $\left(\mathrm{pH}, \mathrm{P}\right.$, and $\left.\mathrm{K}^{+}\right)$, regardless of fertilization type, the variability was higher when the screw-augerwas used than when using the cut- shovel, especially for phosphorus. Alvarez and Guarçoni (2003) also studyingboth instruments, ascertained that the $\mathrm{P}$ showed greater variability for $\mathrm{Mg}^{2^{+}}, \mathrm{K}^{+}, \mathrm{MO}$, and $\mathrm{pH}$, with higher values for the auger. The influence of different sampling methodsin the results of soil analysis were also reported by other researchers (Bacchi et al., 1995; Alvarezand Guarçoni, 2003; Lin et al., 2005; Guarçoni et al., 2007; Oliveira et al., 2007; Wang et al., 2008).

Thus, this study attempts to determine the minimum number of simple samples that theoretically should be used to form a representative composite sample of the depths $0-10,10-20,20-30$ for the chemical parameters: $\mathrm{pH}, \mathrm{P}, \mathrm{K}^{+}, \mathrm{Ca}^{2+}$ and $\mathrm{Mg}^{2+}$, and attempt to show that the estimated average fertility from the arithmetic mean of the results of simple samples does not differ statistically from that estimated from the chemical analysis of the composite sample, in addition to evaluate the effects of data collectioninstruments (auger, cut-shovel and cupauger) at a depth of $0-10$ in the main indices of soil fertility.

\section{MATERIALS AND METHODS}

The study was conducted near the city of Arcoverde, State of Pernambuco-PE (2010). The city has a total area of $379 \mathrm{~km}^{2}$, located at $663 \mathrm{~m}$ an altitude and according to Köppen, a predominance of the climate 'BSHS' type (dry steppe climate of low latitude with rains between autumn-winter) with annual average temperature of $24^{\circ} \mathrm{C}, 1058.8 \mathrm{~mm}$ annual average rainfall, with the rainy season in March and April.

The "Portal do Sertão" as Arcoverde is known, is located in the microregion of the Sertão de Moxotó, transition between the Agreste and Sertão. The city is $256 \mathrm{~km}$ away from Recife, bordered by the BR-232, having as limits: the State of Paraíba to the north, the cities of Pernambuco Buíque and Pedra to the south, Pesqueira to the east and Sertânia the west. It presents a basin bounded by the rivers Moxotó, Ipanema and Ipojuca with subperenifolia forest vegetation and a clay soil type (lbge, 2000).

The total area of the studied fragment has 35 ha in length, with hypoxerophyticcaatinga vegetation that according to the owner has not been clear cut or burned for about 56 years; however it has been used for cattle grazing. The fragment is cut by a temporary stream, whose width varies from 2-24 m, which is called the Riacho da Beija Mão. The aforementioned area, belonging to the Cavalcanti farm, is located near the town of Ipojuca at the margins of PE 219, $22 \mathrm{~km}$ distant from the county seat, Arcoverde/PE.

To determine the number of samples that theoretically should be used to form a representative composite sample representative for chemical characteristics $\left(\mathrm{pH}, \mathrm{P}, \mathrm{K}^{+}, \mathrm{Ca}^{2+}\right.$ and $\left.\mathrm{Mg}^{2+}\right)$, samples were collected from 40 plots installed in the fragment of $10.0 \mathrm{~m} \times 25,0$ $\mathrm{m}$. In these plots were performed samplings via auger at $0-10,10-$ 20 and $20-30 \mathrm{~cm}$ depth with three replicates each, totaling 120 samples for each depth. Subsequently for each plot, subsamples of the three samples collected were used to form a composite sample.

Soil samples were packed in plastic bags, properly identified and then taken to the Department of Soil Chemistry-UFRPE, in which they were air dried and sieved in $2 \mathrm{~mm}$ mesh sieve, obtaining the air-dried fine soil (ADFS).

From the ADFS, $\mathrm{Ca}^{2+}$ and $\mathrm{Mg}^{2+}$ were determined by titration (Embrapa, 1997), $\mathrm{P}$ was measured by colorimetry (Braga and Defelipo, 1974), $\mathrm{K}^{+}$was determined by flame photometry and $\mathrm{pH}$ 
Table 1. Number of samples $(n)$ per soil collection at different depths in a caatinga area, considering different ranges of variation ( $f$ ) to estimate mean values of soil chemical characteristics ( $\mathrm{pH}, \mathrm{P}, \mathrm{K}, \mathrm{Ca}$ and $\mathrm{Mg}$ ) at 95\% probability (Arcoverde - PE, 2011).

\begin{tabular}{|c|c|c|c|c|c|c|c|c|c|c|c|c|c|c|c|}
\hline \multirow{3}{*}{ f (\%) } & \multicolumn{15}{|c|}{ Error compared to the mean value } \\
\hline & \multicolumn{5}{|c|}{$0-10$} & \multicolumn{5}{|c|}{$10-20$} & \multicolumn{5}{|c|}{$20-30$} \\
\hline & $\mathrm{pH}$ & $\mathbf{P}$ & $\mathrm{K}$ & $\mathbf{C a}$ & $\mathbf{M g}$ & $\mathrm{pH}$ & $\mathbf{P}$ & $\mathrm{K}$ & $\mathrm{Ca}$ & $\mathrm{Mg}$ & $\mathrm{pH}$ & $\mathbf{P}$ & $\mathrm{K}$ & $\mathrm{Ca}$ & $\mathbf{M g}$ \\
\hline 10 & 1 & 66 & 31 & 30 & 57 & 1 & 67 & 61 & 22 & 49 & 1 & 146 & 144 & 22 & 29 \\
\hline 20 & 1 & 17 & 8 & 7 & 14 & 1 & 17 & 15 & 6 & 12 & 1 & 37 & 36 & 5 & 7 \\
\hline 30 & 1 & 7 & 3 & 3 & 6 & 1 & 7 & 7 & 2 & 5 & 1 & 16 & 16 & 2 & 3 \\
\hline 40 & 1 & 4 & 3 & 2 & 4 & 1 & 4 & 4 & 1 & 3 & 1 & 9 & 9 & 1 & 2 \\
\hline 50 & 1 & 3 & 1 & 1 & 2 & 1 & 3 & 2 & 1 & 2 & 1 & 6 & 6 & 1 & 1 \\
\hline 60 & 1 & 2 & 1 & 1 & 2 & 1 & 2 & 2 & 1 & 1 & 1 & 4 & 4 & 1 & 1 \\
\hline 70 & 1 & 1 & 1 & 1 & 1 & 1 & 1 & 1 & 1 & 1 & 1 & 3 & 3 & 1 & 1 \\
\hline 80 & 1 & 1 & 1 & 1 & 1 & 1 & 1 & 1 & 1 & 1 & 1 & 2 & 2 & 1 & 1 \\
\hline 90 & 1 & 1 & 1 & 1 & 1 & 1 & 1 & 1 & 1 & 1 & 1 & 2 & 2 & 1 & 1 \\
\hline 100 & 1 & 1 & 1 & 1 & 1 & 1 & 1 & 1 & 1 & 1 & 1 & 1 & 1 & 1 & 1 \\
\hline $\mathrm{CV}(\%)$ & 4 & 40 & 26 & 26 & 37 & 4 & 40 & 38 & 23 & 34 & 4 & 59 & 60 & 23 & 26 \\
\hline
\end{tabular}

$\mathrm{n}=[(\mathrm{t} \alpha / 2 . \mathrm{CV}) / \mathrm{f}]^{2} ; \mathrm{t}_{0,05}(39 \mathrm{DF})=2.03 ; \mathrm{CV}$, Coefficient of variation.

by the soil:water (1:2.5) (Embrapa, 1997).

From this data, the mean and coefficient of variation for each of the sampled depths were determined. Subsequently, the minimum number of simple samples that theoretically should be used to form a composite sample representative of the plot were determined according to the statistical procedure adopted by Barreto et al. (1974): $n=[(t a / 2 . C V) / f]^{2}$, where $n=$ number of simple samples to form a representative composite ta $/ 2=$ tabulated value of the Student's $t$ distribution which depends on the $\alpha / 2$ probability level (two-tailed), with a significance level of $95 \%$ and the number of degrees of freedom ( $d f=n-1$ ), which was calculated by DF interpolation corresponding to 30 and 40 , and its adopted value of $2.03, \mathrm{CV}=$ coefficient of variation of the soil characteristic to be measured; $f=$ angular error around the mean (\%).

In order to try to show that the average fertility estimated from the arithmetic mean of the results of simple samples does not differ statistically from that estimated from the chemical analysis of the composite sample, composite samples were formed from each replicate subsamples collected at each of 40 plots. Thus, there wasthe additional formation of more than 40 samples for each depth. The samples were analyzed $\left(\mathrm{pH}, \mathrm{Ca}^{2+}, \mathrm{Mg}^{2+}, \mathrm{K}^{+}\right.$and $\left.\mathrm{P}\right)$ and data compared with the simple samples by applying the Student's $t$ test.

To evaluate the effects of the different data collection instruments (auger, cut-shovel and cup-auger) on the main indices of soil fertility, additional samples were collected at a depth of 0 to 10 in 16 plots of the original 40 plots delineated. Subsequently, the samples were stored, identified and taken for analysis. The following parameters were evaluated: $\mathrm{pH}, \mathrm{Ca}^{2+}, \mathrm{Mg}^{2}{ }^{+}, \mathrm{K}^{+}$and $\mathrm{P}$ and the Tukey test was applied after data tabulation. Testing was performed using the Assist at software.

\section{RESULTS AND DISCUSSION}

The minimum number of individual samples that should be used to form a composite sample representative for fertility rates of the sampled area was calculated by the coefficient of variation for an error and around the mean of 10 to $100 \%$. In this study, it is observed that as the angular error decreases from 100 to $10 \%$, the minimum number of samples increases to all parameters evaluated, except for $\mathrm{pH}$, where it was noted less spatial variability at all depths analyzed (Table 1). This indicates that this feature should not be used as an indicator to determine the number of simple samples to make a composite sample (Araujo and Oliveira, 2003).

Among the fertility attributes evaluated, the one that estimated the highest number of simple samples required for the soil composite sample was phosphorus, corroborating the results of Hernandez et al. (2011), Silveira et al. (2000), Alvarez and Guarçoni (2003) and Oliveira et al. (2007). For this variable, the number of samples remained constant depth for the first 2 depths $(0-10$ and $10-20 \mathrm{~cm})$ considering $f$ between 10 and $20 \%$, which had its value more than doubled in the depth of 20$30 \mathrm{~cm}$, requiring 146 samples. Increasing the sampling depth increases the number of samples to be collected for $\mathrm{K}^{+}$by more than $50 \%$, being necessary respectively for each depth 31,61 and 144 samples (Table 1). This result confirms the data of Salet et al. (1996) for evaluations of $\mathrm{P}$ and $\mathrm{K}^{+}$in a given crop area considering $10 \%$ error, where the authors found a high number of samples were required to obtain reliable results.

Contrary to this observation, it was noted that a decreased number of samples would be required to form a composite sample for $\mathrm{Ca}^{2+}$ and $\mathrm{Mg}^{2+}$. Assuming $10 \%$ for $\mathrm{f}$ to determine the sampling of $\mathrm{Ca}^{2+}$ and $\mathrm{Mg}^{2+}, 30$ and 57 samples, respectively, would be needed for the 0 to $10 \mathrm{~cm}$ depths, while for the 20 to $30 \mathrm{~cm}$ depths, this number decreases to 22 and 29, respectively (Table 1 ).

The average values for $\mathrm{P}, \mathrm{K}, \mathrm{Mg}$ and $\mathrm{pH}$ were consistently higher for samples collected with Dutch auger and cup-auger when compared with the cut-shovel, indicating that this sampling method is better suited for 
Table 2. Means $(\mathrm{Y})$ for phosphorus, potassium, calcium, magnesium and $\mathrm{pH}$ in soil samples collected in the caatinga area of 16 plots with different data collection instruments (Arcoverde - PE, 2011).

\begin{tabular}{|c|c|c|c|c|c|}
\hline \multirow{3}{*}{$\begin{array}{l}\text { Data collection } \\
\text { instrument }\end{array}$} & $\mathrm{pH}$ & $\mathbf{P}$ & $\mathrm{K}$ & $\mathbf{C a}$ & $\mathrm{Mg}$ \\
\hline & \multicolumn{2}{|c|}{$\mathrm{mg} \mathrm{dm}^{-3}$} & \multicolumn{3}{|c|}{ cmolcdm $^{-3}$} \\
\hline & \multicolumn{5}{|c|}{$Y$ (means) } \\
\hline Dutch auger & $6.21^{a}$ & $2.892^{\mathrm{a}}$ & $0.297^{\mathrm{a}}$ & $4.8739^{\mathrm{a}}$ & $1.9479^{\mathrm{a}}$ \\
\hline Cut-shovel & $5.96^{\mathrm{b}}$ & $1.718^{b}$ & $0.2089^{a}$ & $5.0093^{\mathrm{a}}$ & $1.5437^{b}$ \\
\hline Cup-auger & $6.09^{a b}$ & $2.664^{\mathrm{a}}$ & $0.2104^{\mathrm{a}}$ & $5.7606^{\mathrm{a}}$ & $1.9268^{\mathrm{a}}$ \\
\hline $\mathrm{F}$ & $3.211^{*}$ & $19.5635^{\star *}$ & $3.048^{\text {ns }}$ & $1.992^{\text {ns }}$ & $4.2599^{*}$ \\
\hline CV\% & 4.638 & 23.207 & 48.73946 & 25.95966 & 24.41272 \\
\hline
\end{tabular}

Means followed by same letter for each data collection instrument do not differ significantly by the Tukey test at $5 \%$.

${ }^{* *}$, Significant at $1 \%$ probability $(p<.01)$; ${ }^{*}$, significant at $5 \%$ probability $(.01=<p<.05)$; ns, not significant $(p>=.05)$

the three depths studied, except for calcium analysis. Oliveira et al. (2007) also found that the variability of soil fertility indices were similar among the data collection instruments, observing higher values for the cup-auger than cut-shovel, except for $\mathrm{K}^{+}$and $\mathrm{Ca}$. However, in soybean and corn crop areas, Salet et al. (2005) observed lower values of fertility rates in samples collected with the Dutch auger compared with the cutshovel.

Thus, the results obtained in this study depending on the sampling method have a clear influence on the results of soil analysis, as reported by several authors (Bacchi et al., 1995; Alvarez and Guarçoni, 2003; Lin et al., 2005; Guarçoni et al., 2007; Oliveira et al., 2007; Wang et al., 2008). Significant differences among instruments were observed for $\mathrm{pH}, \mathrm{P}$ and $\mathrm{Mg}$ and regardless of the instruments, the lowest variability was observed for $\mathrm{pH}$. The variability order was different for both collection instruments, being represented indecreasing order as follows: Dutch auger $\mathrm{Ca}^{2+}>\mathrm{P}>$ $\mathrm{Mg}^{2+}>\mathrm{K}>\mathrm{pH}$; Cut-shovel $\mathrm{K}>\mathrm{Mg}^{2+}>\mathrm{P}>\mathrm{Ca}^{2+}>\mathrm{pH}$ and cup-auger $\mathrm{K}>\mathrm{Ca}^{2+}>\mathrm{P}>\mathrm{Mg}^{2+}>\mathrm{pH}$ (Table 2 ).

Comparing the fertility indices for the average of single samples (120 samples) with the average of composite samples consisting of three simple subsamples, no significant differences were found when using the Student's t test at $5 \%$. Samples collected from the 20 to $30 \mathrm{~cm}$ depth resulted in higher values of $\mathrm{Ca}^{2+}$ and $\mathrm{Mg}^{2+}$, though not significantly different compared to the average of composite samples (Table 3 ). These results indicate that, probably, if a smaller number of single samples is collected, the averages of these characteristics would not be different regardless of the evaluation method of average soil fertility. Oliveira et al. (2007) reported that regardless of the sampling method for assessment of average soil fertility (arithmetic mean of simple samples or chemical analysis of the composite sample), the number of single samples to form one composite sample does not influence the estimate of the average contents of evaluated characteristics of fertility, as observed in this work. However, this author emphasizes that the collection of at least eight individual soil samples would be sufficient to form a representative composite sample for evaluation of the average soil fertility in an apparently homogeneous sampling unit. With other later studies, similar results were observed (Santos et al., 2009).

Considering the most limiting attribute and the percentage error in estimating the average of $20 \%$, the number of simple samples can range from 50-188 (Silveira et al., 2000); from 11-183 (Schlindwein and Anghinon, 2002); 20-39 (Guarçoni et al., 2006), 5 to 20 (Guarçoni et al., 2007), 18-31 (Amaro Filho et al., 2007). Guarçoni et al. (2006) recommend, for the characterization of the soil individual (sample unit), a collection of 25 simple samples to compose a representtative composite sample, taking into account "f" around $20 \%$.

According to the statistical formula that determines the number of simple samples to form a representative composite (Barreto et al., 1974), the collection of more simple samples (higher $n$ value) has no influence on the average value of the chemical characteristic of the soil evaluated, but increases the reliability or accuracy of this mean value obtained by decreasing the "f" value.

\section{Conclusion}

Increasing the depth of sampling required increases the quantity of collected samples for $\mathrm{P}$ and $\mathrm{K}^{+}$, while for $\mathrm{Ca}^{2+}$ and $\mathrm{Mg}^{2+}$, this number is expected to decline and remains stable for $\mathrm{pH}$. There were significant differences in fertility values obtained with the three instruments used in the collection for $\mathrm{pH}, \mathrm{P}$ and $\mathrm{Mg}^{2+}$ with the cut shovel instrument giving the lowest fertility values.

The reliability of the sample was influenced by soil depth and instrument used. As regards the depth, below $0.2 \mathrm{~m}$, the number samples to be at maximum for proper estimations of phosphorus and potassium levels in soils.

Considering the major homogeneity of subsurface layer, due to the minor influence of topsoil, a smaller number of samples cam be taken for de variables $\mathrm{pH}$, $\mathrm{Ca}^{2+}$ and $\mathrm{Mg}^{2+}$, as published by other research.

The instruments used have changed the contents the 


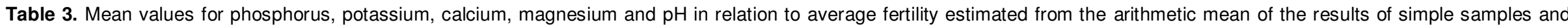
estimated from the chemical analysis of the composite sample (Arcoverde - PE, 2011).

\begin{tabular}{|c|c|c|c|c|c|c|c|c|c|c|c|c|c|c|c|}
\hline \multirow{3}{*}{ Depth } & \multicolumn{5}{|c|}{$0-10$} & \multicolumn{5}{|l|}{$10-20$} & \multicolumn{5}{|l|}{$20-30$} \\
\hline & $\mathrm{pH}$ & $P$ & $\mathrm{~K}$ & $\mathrm{Ca}$ & $\mathrm{Mg}$ & $\mathrm{pH}$ & $\mathbf{P}$ & $\mathrm{K}$ & $\mathrm{Ca}^{\mathrm{a}}$ & $\mathrm{Mg}$ & $\mathrm{pH}$ & $\mathbf{P}$ & $\mathrm{K}$ & $\mathrm{Ca}^{\mathrm{a}}$ & $\mathrm{Mg}$ \\
\hline & \multicolumn{2}{|c|}{$\mathrm{mg} \mathrm{dm}^{-3}$} & \multicolumn{3}{|c|}{$\mathrm{cmolcdm}^{-3}$} & \multicolumn{2}{|c|}{$\mathrm{mg} \mathrm{dm}^{-3}$} & \multicolumn{3}{|c|}{$\mathrm{cmolcdm}^{-3}$} & \multicolumn{2}{|c|}{$\mathrm{mg} \mathrm{dm}^{-3}$} & \multicolumn{3}{|c|}{$\mathrm{cmolcdm}^{-3}$} \\
\hline Simple samples & $6.18^{a}$ & $2.385^{a}$ & $0.28951^{a}$ & $4.80667^{a}$ & $2.05917^{a}$ & $6.17^{a}$ & $1.630^{\mathrm{a}}$ & $0.28951^{a}$ & $4.70583^{a}$ & $2.22792^{\mathrm{a}}$ & $6.07^{\mathrm{a}}$ & $0.907^{a}$ & $0.29423^{a}$ & $4.56075^{a}$ & $2.00392^{a}$ \\
\hline Composite samples & $6.18^{a}$ & $2.409^{a}$ & $0.31706^{a}$ & $4.92500^{\mathrm{a}}$ & $1.99525^{\mathrm{a}}$ & $6.15^{a}$ & $1.789^{a}$ & $0.31706^{a}$ & $4.62750^{a}$ & $2.10750^{a}$ & $6.09 \mathrm{a}$ & $1.115^{a}$ & $0.31841^{a}$ & $4.80125^{a}$ & $2.20925^{a}$ \\
\hline
\end{tabular}

Means followed by same letter in column do not differ significantly by the Student's t test at $5 \%$.

elements obtained in sampling, interfering in the evaluation of levels available, performing as an important component to be considered in sampling of soils. There was no significant difference between the average of simple samples and the average of composite samples in relation to fertility rates.

\section{REFERENCES}

Almeida Neto JX (2008). Estrutura fitossociológica, crescimento e bromatologia do feijão-bravo (Capparis flexuosa (L) no Curimataú paraibano, Brasil p.57. Dissertação (Mestrado em Agronomia). Centro de Ciências Dissertação (Mestrado em Agronomia). Centro de

Agrárias, Universidade Federal da Paraíba, Areia.
Alvarez VVH, Guarçoni MA (2003). Variabilidade horizontal dafertilidade do solo de uma unidade de amostragem em sistemaplantio direto. Revista Brasileira de Ciência do Solo 27:297-310.

Alves JJA (2007). Geoecologia da caatinga no semi-árido do Nordeste brasileiro. Climatologia e Estudos da Paisagem. 2(1): 5871 .

Amaro Filho J, Negreiros RFD, Assis JuniorRN, Mota JCA (2007). Amostragem e variabilidade espacial deatributos físicos de um Latossolo Vermelho em Mossoró, RN.Revista Brasileira Ciência do Solo 31: 415-422.

Araujo PMDB, Oliveira M (2003). Variabilidade espacial de cálcio, magnésio, fósforo e potássio em solos das regiões

oeste e do Baixo Açu, estado do Rio Grande do Norte. Caatinga (16)1: 69-78.

Barreto AC, Novais RF, Braga JM (1974). Determinação estatística do número de amostras simples de solo por área para avaliação de sua fertilidade. Revista Ceres 21: 142147.

Bacchi GS, Sparovek G, Franco APB (1995). Influência de diferentes métodos de coleta de amostras, no resultado de análise de terra. In: CONGRESSO BRASILEIRO DE CIÊNCIA DO SOLO, Viçosa. Anais... Viçosa: SBCS. pp. 589-591.

Braga JM, Defelipo BV (1974). Determinação espectrofotométrica de fósforo em extratos de solo material vegetal. Revista Ceres 21: 73-85.

Coráje JE (1997). The potential for site-specific management of soil and yield variability induced by tillage. East Lansing, Michigan State University. p. 104

Embrapa - Empresa Brasileira de Pesquisa Agropecuária 1997). Manual de métodos de análise de solo. Brasília: CNPS. p. 212.

Fernandes AG (1998). Conjuntos vegetacionais brasileiros. Fortaleza: Editora UFC. p. 128

Guarconi MA, Alvarez VVH, Novais RF, Cantarutti RB, Leite HG, Freire FM (2006). Definição da dimensão do indivíduo solo e determinação do número de amostras simples necessário à sua representação. Revista Brasileira de Ciência do Solo 30: 943-954.

Guarçoni MA, Alvarez VVH, Novais RF, Cantarutti, RB, Leite HG, Freire FM (2007). Diâmetro de trado necessário à coleta de amostras num Cambissolo sob plantio direto ou sob plantio convencional antes ou depois da aração. Revista Brasileira de Ciência do Solo 31: 947-959.

Hernandez A, Rozane DE, SpuzaHÁ, Romualdo LM,Natale W (2011). Amostragem para diagnose do estado nutricional avaliação da fertilidade do solo em caramboleiras. Bragantia [online]. 70(3): 657-663.

lbge. Manual técnico da vegetação brasileira (1992). Rio de Janeiro, 92 p. (Série Manuais Técnicos em Geociências,1). lbge (2000). Censo do Município de Arcoverde-PE. Arcoverde. p.8.

Lin H,Wheeler D, Bell J, Wilding L (2005). Assessment of soil spatial variability at multiple scales.EcologicalModeling. 182:271-290.

Oliveira FHT, Arruda JÁ, Silva IF, Alves JC (2007). Amostra- gem para avaliação da fertilidade do solo em função do instrumento de coleta das amostras e de tipos de preparo do solo. Revista Brasileira de Ciência do Solo, 31: 973-983.

Paupitz J (2009). Manejo florestal sustentável da Caatinga e desafios. In: Curso para Organização de Assistência Técnica sobre manejo florestal sustentável de uso múltiplo da Caatinga.Patos.

Prado D (2003). As caatingas da América do Sul. In: I.R. Leal, M. Tabarelli \& J.M.C. Silva (eds.). Ecologia e conservação da Caatinga: 3-73. Editora Universitária, Universidade Federal de Pernambuco, Recife, Brasil.

Salet RL, Kray CH, Fornari TG, Conte E, Kochhann RA, Anghinoni I (1996). Variabilidade horizontal e amostragem de solo no sistema plantio direto. In: Reunião Sul-Brasileira De Ciência Do Solo, 1., Lages, 1996. Resumos Expandidos. Lags, Sociedade Brasileira de Ciência do Solo. pp. 74-76.

Salet RL, Nicolodi M, Bisso FP (2005). Eficácia do trado holandês na amostragem de solo em lavouras no sistema plantio direto. Revista Brasileira de Agrociência. 11(4): 487491

Santos HC, Oliveira FHT, ArrudaJÁ, Lopes ARS, Junior RFS, Farias DR (2009). Amostragem para avaliação da fertilidade do solo em função da variabilidade de suas características químicas. Revista Brasileira de Engenharia Agrícola $e$ Ambiental, 13: 849-854.

Schlindwein JÁ, Anghinoni I (2002). Tamanho da subamostra erepresentatividade da fertilidade do solo no sistema plantio direto. Ciência Rural. 32: 963-968.

Silveira PM, Zimmermann, FJP, Silva SC, Cunha AA (2000). Amostragem e variabilidade espacial de características químicas de um Latossolo submetido a diferentes sistemas de preparo.PesquisaAgropecuária Brasileira. 35: 2057 2064.

Wang Y, Feng N, LiT,Zhang XIZ,Liao G (2008). Spatial variability of soil cation exchange capacity in Hilly tea plantation soils under different sampling scales. Agric. Sci. China 7: 96-103. 